\title{
Wisdom and Folly in the city: exploring urban contexts in the book of Proverbs
}

\author{
Katharine J. Dell \\ University of Cambridge, West Road, Cambridge CB3 9BS, UK \\ kjd24@cam.ac.uk
}

\begin{abstract}
Proverbs 1-9 is often said to have a city background that contrasts with the agricultural imagery dominant in the maxims sections. However, this is an oversimplification. There are also maxims in the main Proverbs collection that concern the city, and the city background revealed within Proverbs 1-9 links up with the portrayal of the 'capable wife' in Proverbs 31:10-33. Having established the presence of city references throughout Proverbs, this article explores how the portrayal of Woman Wisdom and Woman Folly in particular gives fascinating insight into the heart of happenings in the Israelite city.
\end{abstract}

Keywords: city, Folly, maxims, Proverbs, urban, Wisdom

To enter the book of Proverbs is ostensibly to enter two entirely different worlds - the urban and the rural. The city background of Proverbs 1-9 is widely acknowledged. ${ }^{1}$ As R. Norman Whybray writes, 'The situation is urban rather than rural, and the social status presupposed is high'. ${ }^{2}$ Likewise the large swathes of maxims in the book are assigned to a village or small town, largely agricultural background, and to an oral context, even if their subsequent putting into writing was ultimately a more literate, hence urban, concern. Again Whybray writes of these maxims, 'they are examples of the traditional lore of 'wisdom' of ordinary people, mainly small farmers who lived in the towns and villages of ancient Israel'. ${ }^{3}$ These two social contexts within Proverbs are seen as very distinct, and the different genres of material helpfully match this distinction, with more literary instruction texts and poems characterising Proverbs 1-9, and basic-level, originally oral, maximmaking characterising Proverbs 10:1-22:17, as well as chapters 25-30. The

1 Along with parts of Prov 22:17-24:22 and 31, see below.

2 R. N. Whybray, The Composition of the Book of Proverbs, JSOTS 168 (Sheffield: Sheffield Academic Press, 1994), p. 56. He is the scholar who has written most upon this subject in relation to wisdom literature.

3 Ibid., p. 62. 
dichotomy between the two goes further still, with the city symbolising wealth, power, literacy, education and culture and the rural symbolising the oral, the primitive and the struggle not to fall into poverty, laziness or even foolishness. There are also ramifications for dating each section, with the presupposition that the rural preceded the urban, the two contexts ultimately coming together under the late introductory 'prologue' of Proverbs 19. ${ }^{4}$ The question I wish to pose in this article is why this distinction is drawn so sharply between the different sections of Proverbs, and whether this dichotomy has not been somewhat too enthusiastically taken up and perpetuated in the scholarship in relation to questions of context and literary genre. This prompts the question of how the 'city' portrayal in Proverbs 1-9 is to be characterised and understood. At the centre of this portrayal stands another pair of opposites - that between Woman Wisdom and Woman Folly - who between them, I would argue, hold the key to the city imagery in this biblical wisdom book.

\section{References to the city in the maxims sections of Proverbs}

עיר are found here main interchangeable terms for city, עריה and are occurs in 16:32;21:22;25:28 and קריה in 10:15;11:10;18:11,19 and 29:8, with קרת in 11:11. Whybray suggests that most of these references are figurative or do not imply a city setting. He argues that the impression is given of 'a rather small community whose inhabitants are mutually acquainted'. 5 Let us look at the evidence. In 16:32b the person who controls their temper is compared favourably to 'one who captures a city' (עיר). Yoder makes the crisp remark that the sense of this proverb is that 'one cannot conquer the world without first conquering oneself' ${ }^{6}$ The wider context is 16:32a, 'One who is slow to anger is better than the mighty'. The inference is that anger and haste are key factors in the success of those attempting to fight for

${ }^{4}$ I do not wish to discuss dating issues here. Suffice to say that in my view there are early features of Proverbs 1-9 which do not make a late dating for the whole conclusive (see Katharine J. Dell, The Book of Proverbs in Social and Theological Context (Cambridge: CUP, 2006)), and that such a developmental view from oral to literary and from one set of genres to another is oversimplified and out of favour generally in current scholarship. See e.g. Susan Niditch, Oral World and Written Word: Ancient Israelite Literature (Louisville, KY: Westminster John Knox Press, 1996), who speaks of an oral/literary continuum over a long period of time.

${ }^{5}$ R. Norman Whybray, 'City Life in Proverbs 1-9', in A. A. Diesel, R. G. Lehmann, E. Otto and A. Wagner (eds), 'Jedes Ding hat seine Zeit ... ': Studien zur israelitischen und altorientalischen Weisheit, Diethelm Michel zum 65 Geburtstag, BZAW 241 (Berlin: Walter de Gruyter, 1996), pp. 243-50.

${ }^{6}$ Christine R. Yoder, Proverbs, Abingdon OT Commentaries (Nashville, TN: Abingdon Press, 2009), p. 189. 
control of a city. Of course this tells us little about a city background, but it does presuppose that this kind of capturing of cities took place and could be characterised to an audience who were inwardly digesting the point of the comparison. In 21:22 'One wise person went up against a city (עיר) of warriors and brought down the stronghold in which they trusted'. This short vignette is an attack on 'warriors' who are perceived to dwell in a city. It could relate the capture of city by the ruler or king of another, ${ }^{7}$ or it could be praising the existence of one wise person over a whole city of warriors. ${ }^{8}$ The city as a protected place is compared to a stronghold. This suggests that power was more concentrated in cities, which acted as centres for controlling the surrounding area. It is a warning also about the potential overreaching of the mighty and powerful, their pride and their misplaced trust in their own strength. Proverbs 25:28 reads, "Like a city (עיר) breached, without walls, is one who lacks self-control'. Here the image that the city affords is one of unity, strength, organisation and cohesiveness, to which a person's individual lack of self-control is usefully likened (cf. 16:32). The listener or reader would need to have a familiarity with the richness of the image of the city being used here.

In 10:15 wealth is compared to a fortified city (קריה) or fortress. Money is the protective fortification of the rich which is contrasted with the poverty of the poor that is their ruin. This proverb doesn't actually state that the city is a place for the monied, although the choice of imagery may suggest it. Proverbs 11:10 reads 'When it goes well with the righteous, the city rejoices; and when the wicked perish, there is jubilation.' This suggests that the whole community has an involvement in the righteous/wicked prosperity/perishing nexus that is so common in Proverbs. The city here represents a unified group of people of common mind. This is followed by 11:11 and should probably be read in a pair with it, since it gives the reason for the rejoicing: 'By the blessing of the upright a city (קרת) is exalted but it is overthrown by the mouth of the wicked.' This is again the idea of a whole community being influenced, but this time for good, by the good behaviour of the upright. Fox suggests that the righteous actively pronounce blessing on the city (in the light of the destructive speech of the wicked in the second part of the line) rather than its being a passive receipt of blessing here. ${ }^{9}$ Again the upright/wicked contrast is used. Proverbs 18:11 picks up the same idea as 10:15 (with which the first line is shared) and 21:22, that

7 See Michael V. Fox, Proverbs 10-31 (New Haven and London: Yale University Press, 2009), p. 689.

8 So Yoder, Proverbs, p. 220.

9 Fox, Proverbs 1-9, p. 535. 
the wealth of the rich is their strong or fortified city. Here an expanding thought is added: 'in their imagination it is like a high wall'. There could be some irony in the suggestion that the rich have more faith in their wealth than is justified, and that the city, like money, can be a false refuge. This same 'strong city' reappears later in the chapter in verse 19 where 'an ally offended is stronger than a city; such quarrelling is like the bars of a castle'. The focus here is on the fortification: the point is that just as fortifications and barred gates cannot be broken down or crossed, so the person with whom one has a strong dispute. The inference could be that the ally or brother shuts the disputant out emotionally, ${ }^{10}$ or that an offence can lead even the more loyal person to 'impenetrable resentment', as if barring the gates of a city. ${ }^{11}$ It is interesting that this characterisation of the city as a stronghold or fortification recurs a number of times in these maxims. In 29:8, 'scoffers set a city aflame', and this is contrasted with the wise who turn anger away. This gets across the idea of the ease of a mocking tongue in influencing a large number of people in the close-knit proximity of a city (cf. Isa 28:14, where the scoffers are corrupt rulers). This might refer to ideas that are politically inflammable, it being better to calm public passions down, ${ }^{12}$ although it may just refer to stirring up anger and conflict in the community in general.

One has to remember that the image of a city is used in the service of moral formation in these maxims, and so the mention of a city is not the prime point of a saying. ${ }^{13}$ The use of the language is figurative, as Whybray notes, and one does not have to be in a city to speak about it. ${ }^{14}$ Having said that, however, the point of a comparison in any proverb is lost if the terms of reference are not understood, and so we must assume a certain familiarity with the city concept and what that symbolised amongst the audience addressed. Even from this short list of maxims one gets an impression of what the city stood for: it is seen as tight, strong and fortified, a place of refuge, a place easily swayed by opinion, a place where numbers count. ${ }^{15}$ It is also a place associated with the wealthy and the powerful, although not exclusively so.

10 So Fox, Proverbs 1-9, p. 644.

11 Yoder, Proverbs, p. 200.

12 So Fox, Proverbs 1-9, p. 836.

13 Other images are used in the maxims section that could indicate any town or city, e.g. 'streets' in 22:13 or 'at the gate' in 22:22. Little can be built on these wider references.

14 Whybray, 'City Life in Proverbs 1-9'.

15 The presence of walls usually distinguishes cities from villages in the Old Testament, notably in Josh 19:16; Neh 11:30; Num 21:25 and 2 Chron 13:19. A walled city is often assumed in the maxims of Proverbs, as well as being a relevant category for Proverbs 1-9. I am grateful to my Ph.D. student Arthur Keefer for supplying these references and for reading the article with a critical eye. 
Cities were also desirable places which were fought over and which acted as a focal point for communities. Whybray's 'small town' idea doesn't really seem to fit this evidence. The 'city' often represents a close-knit group with common opinions; they are easily 'swayed' as a group, but that doesn't mean they all know each other or are 'more aware of the behaviour of their neighbour's children', as Whybray expresses it. ${ }^{16}$ The impression is being given that just as 'the righteous' and 'the wicked' are stylised groups (in that no one can be completely righteous or indeed completely wicked), so the symbol of the city is also rather stylised in this material. It is important that people know what it represents in clear-cut terms, and that there are no grey areas. It is interesting, too, that I have been able to establish the main elements of the urban from the maxims section alone, without any reference to the rest of the book, so suggesting that these maxims should not be downplayed in importance in gaining a full picture of city life, since the city is not absent from this section, nor exclusively the preserve of Proverbs 1-9.

\section{Social indicators in Proverbs $23: 18 ; 23: 29-35$ and $31: 1-10$}

Proverbs 22:17-24:22, notably 23:1-8 and 23:29-35, is another section of Proverbs that contains some reference to the high life, even though it does not contain city references per se. This is the section that is commonly likened to the Egyptian Instruction of Amenemope, and that discussion has tended to dominate any other findings in this section. ${ }^{17}$ Proverbs $23: 1-8$ speaks of table manners when dining with rulers. Whybray writes of its opening verses, 'These verses [1-3] may well have been written with an eye to smoothing the path of the ambitious pupil bent on getting to the top, and could only be of use in a class of society which gives dinner parties.' ${ }^{18}$ This links up with other proverbs in the main maxims section that refer to the king (notably in chapters 16 and 20-1). The question is raised whether reference to a king necessitates a royal context, or indeed whether any person may speak about the king and

16 Whybray, 'City Life in Proverbs 1-9', p. 250.

17 The Instruction of Amenemope was discovered in 1923 and has had a significant effect on the interpretation both of this section of Proverbs, with which it is seen to share sayings, and on ideas about social context for the whole book. The debate continues as to how far the influence has gone. Against a direct alignment, see R. Norman Whybray, 'The Structure and Composition of Proverbs 22:17-24:22', in S. E. Porter, P. M. Joyce and D. E. Orton (eds), Crossing the Boundaries: Essays in Biblical Interpretation in Honour of Michael D. Goulder (Leiden: Brill, 1994), pp. 83-96. In favour of the link, see John A. Emerton, 'The Teaching of Amenemope and Proverbs XXII 17-XXIV 22: Further Reflections on a Long-Standing Problem', Vetus Testamentum 51 (2001), pp. 431-65.

18 Whybray, Composition, p. 138. 
hence the context be unknown. ${ }^{19}$ It is possible to argue that, unlike the king proverbs, there is in Proverbs 23:1-8 a rather more detailed piece of advice that would be of no use at all to anyone except a courtier or administrator who might well have contact with rulers or kings. This has formed a large part of the 'administrators at the time of the Solomonic enlightenment' argument that was popular in the 1960s and 1970s through the work of von Rad and others. ${ }^{20}$ This section is actually an admonition not to desire the goods of others that are basically out of reach and warns against 'wearing yourself out to get rich'. Riches are fleeting, and those who are rich are often mean - their generosity is false and only directed at their own ends. This section doesn't really add much to our city discussion. It may indicate the class of people who tend to live there, but are they "quite beyond the imaginings of the authors of the "sentence literature", as Whybray maintains? ${ }^{21}$ Nor does 23:29-35 - an admonition against drinking wine - add much. There is no evidence that drinking wine was a particularly city-centred activity, although the prosperous would no doubt have had easier access to it.

Proverbs 31:10-31 is another contender for the city discussion with its portrayal of the 'woman of worth'. This wife, mother and household manager is clearly well-to-do in that she has servants (v. 15), but she is not excessively wealthy - she has to sell needlework and make dresses (vv. 18-19). However she buys luxury food from afar and purchases agricultural property. Again a city background is plausible, but only indicated by the fact that her husband is described as being "known in the city gates, taking his seat among the elders of the land' (v. 23). This suggests that her husband is a man of importance, likely therefore to be one of the ruling class and to live in the city. Another possible indicator is her supplying of clothing to merchants (v. 24) and general access to markets and fine goods. However, this evidence is flimsy at best. A city context has in many ways been assumed for her by comparisons drawn with Woman Wisdom in Proverbs 1-9. A number of scholars have

19 See discussion in Katharine. J. Dell, 'The King in the Wisdom Literature', in John Day (ed.), King and Messiah in Israel and the Ancient Near East, JSOTS 270 (Sheffield: Sheffield Academic Press, 1998), pp. 163-86, suggesting a broader context. See more recently Christopher B. Ansberry, Be Wise my Son, and Make my Heart Glad: An Exploration of the Courtly Nature of the Book of Proverbs, BZAW 422 (Berlin: De Gruyter, 2011), who emphasises the courtly context, but finds a wider ethical application for its values.

${ }^{20}$ Gerhard von Rad, Wisdom in Israel (London: SCM Press, 1972 [1970]); E. W. Heaton, Solomon's New Men (London and New York: Pica Press, 1974). See Katharine J. Dell 'Solomon's Wisdom and the Egyptian Connection', in J. Middlemas, D. J. A. Clines and E. K. Holt (eds), The Centre and the Periphery: Festschrift for W. Brueggemann (Sheffield: Phoenix Press, 2010), pp. 21-36.

21 Whybray, 'City Life in Proverbs 1-9', p. 244. 
argued for this portrayal as an idealised picture and for an inclusion of her with that of Wisdom, seeing them as essentially belonging to the same urban context and both representing ideal archetypes rather than real women. ${ }^{22}$

\section{The depiction of city life in Proverbs 1-9}

Clearly the most fruitful section of Proverbs for any reference to city life is Proverbs 1-9. Here I will argue that the city imagery is primarily focused in the two figures of Woman Wisdom and Woman Folly, and that they are the key to understanding this emphasis in Proverbs 1-9 and for understanding the stylisation of the concept, too. There are perhaps hints of city life in the instruction texts of Proverbs 1-9, for example, in the reference to robbers and gangs as in 1:10-19, perhaps more likely to lurk in the dark corners of a city, although other small-town contexts are equally possible. There is clearly an educational milieu for the instruction material, which could indicate a city context where schools would be more likely, but this conclusion is purely speculative. ${ }^{23}$ More concrete than this, there is frequent reference to architectural features that seem to belong in the city - to houses, gates, doors and walls. Most of these references, though, are within the descriptions or speeches of the two key figures of Proverbs 1-9.

Whybray argues for a city setting for Proverbs 1-9 from the absence of certain features. First he finds no reference to peasant farmers or their occupations in the section, not even in 3:9-10 where agricultural produce is referred to (barns filled with plenty and vats bursting with wine), but where, Whybray says, 'this is intended as a sign of wealth and does not necessarily imply that their owners are themselves farmers or wine producers: rather,

22 See Athalya Brenner, 'Some Observations on the Figuration of Woman in Wisdom Literature', in H. A. McKay and D. J. A. Clines (eds), Of Prophets' Visions and the Wisdom of Sages: Essays in Honour of R N Whybray, JSOTS 162 (Sheffield: JSOT, 1993), pp. 192-208. See also Claudia V. Camp, Wisdom and the Feminine in the Book of Proverbs (Sheffield: Almond Press, 1985), and Claudia V. Camp, Wise, Strange and Holy: The Strange Woman and the Making of the Bible, JSOTS 320 (Sheffield: Sheffield Academic Press, 2000).

23 Bernhard Lang ('Schule und Unterricht im alten Israel', in M Gilbert (ed.), La Sagesse de l'Ancien Testament BETL 51 (Leuven: Leuven University Press, 1979), pp. 186-201) suggested the existence of market-place schools. André Lemaire (Les écoles et la formation de la Bible dans l'ancien Isrä̈l, OBO 39 (Fribourg, Switzerland: Éditions Universitaires; Göttingen: Vandenhoeck \& Ruprecht, 1981)) found schools all over Israel, probably centred in towns and cities. A more cautious view is that schools were probably sporadic - one in Jerusalem, and maybe a few elsewhere. The archaeological evidence is sparse also; see Graham I. Davies, 'Were there Schools in Ancient Israel?', in J. Day, R. P. Gordon and H. G. M. Williamson (eds), Wisdom in Ancient Israel: Essays in Honour of J A Emerton (Cambridge: CUP, 1995), pp. 199-211. 
probably, that they draw their profits ... from their country estates. ${ }^{24}$ I wonder whether one can really infer this. The evidence from 3:9-10 could suggest a more mixed background to the section than Whybray wants to concede here. Whybray also notes that there is little reference to the 'neighbour' who features prominently in the maxims section, although he has to concede two examples: in 3:28-9 and 6:1-5. He writes, 'This is a further indication that this is a city, busy and noisy, in which the intimacy of village life ... is lacking, and the individual is lost in the crowd. ${ }^{25}$ Yet these verses do promote good relations with neighbours and in the subsequent verses avoidance of quarrelling and violence that would really belong in either an urban or a rural context. Third, Whybray remarks on the fact that that there are no references to the poor or to widows in Proverbs 1-9 but does this mean such people were not of concern to city dwellers? This is what Whybray concludes: 'Proverbs 1-9', he writes, 'thus represents the interests of an urban, wealthy, self-satisfied upper class to whom the plight of the urban poor in their midst as well as of the rural poor was of no interest whatever.' 26 One might have thought that poverty and widowhood would be prevalent and of concern in all contexts, urban and rural, and yet the evidence is not there in the text. This suggests again that the portrait of the city is deliberately overdrawn, even within the book of Proverbs itself. This aligns with the very black-and-white view of the world that Proverbs portrays, and its constant use of 'types' rather than the complexity of real characters. Whybray also notes the absence of the 'fool' in Proverbs 1-9 (six times rather than 65 in the sentence literature) and the absence of the 'lazy', too (although the theme is aired in 6:6-11; cf 24:30-4). He notes, too, that the 'rich' are not mentioned as a class in this section, giving the reason for this as, 'because the wealthy do not often refer to themselves in this way'. ${ }^{27} \mathrm{He}$ sees 'rich' in the sentence literature as a hostile term. Certainly these absences are interesting and do suggest different preoccupations between sections. For me it reveals the extent of the dichotomy between the two contexts. However, some of the arguments from absence are not fully decisive. I suggest turning to the figures of Wisdom and Folly for more edification regarding the city context in Proverbs 1-9.

In the first speech of Wisdom in 1:20-33, Wisdom is first described as crying out in the 'street' and in the 'squares', at 'busy corners' and at the 'city gates'. Her urban credentials then are immediately established. This imagery

${ }^{24}$ Whybray, 'City Life in Proverbs 1-9', pp. 247-8.

25 Ibid., p. 248.

${ }^{26}$ Ibid., p. 249.

27 Ibid., p. 248. 
indicates that she is at the centre of human activity in the city. What she has on offer - wealth, prosperity and good fortune - also belongs to the wider picture of city life associated with monetary success and power, although there is nothing fake about the true wealth that she offers $(3: 13-14)$. At the beginning of chapter 8 she is again positioned 'on the heights, beside the way, at the crossroads, beside the gates in front of the town (קרת), at the entrance of the portals' (8:2-3), again in prominent places where she will attract the attention of many people. Later it is made clear that by Wisdom 'kings reign and rulers decree what is just' - the central occupants of the city are in Wisdom's control. Again the riches on offer are described (8:18-19): she holds the key to both social and economic prosperity. ${ }^{28}$ It is later in chapter 8 (vv. 22-31) that Wisdom's close link with the divine is brought out, but then the chapter ends with the admonition to heed the instruction: 'happy is the one who listens to me, watching daily at my gates, waiting beside my doors' (v. 34). An image is created of groups of young men crowding around the doors of Wisdom's house in the hope of hearing her instruction and even entering her domain. The imagery of private houses is used of both Wisdom and her counterpart, but this is also a claiming of all gates and doors that lead to pathways established by Wisdom. At the beginning of chapter 9 (v. 1), Wisdom builds her own house with seven pillars (a known structure?), ${ }^{29}$ and she invites all and sundry to her dinner table. Whybray suggests that this was a 'housewarming' party' ${ }^{30}$ Of course, this may well be a symbolic meal rather than a real one. This too might suggest urban living, along the lines of dining with rulers in 23:1-8. Wisdom is clearly well-to-do - in 9:2 she has slaughtered her own animals to provide food for the feast, and wine is also mentioned; and in 9:3 she sends out her servant-girls and calls to all-comers, even the simple, 'from the highest places in the town' (קרת). But then this is

28 See Timothy J. Sandoval, The Discourse of Wealth and Poverty in the Book of Proverbs (Leiden: Brill, 2005).

29 This reference to Wisdom's house has generated some discussion amongst scholars. See Balint Zaban, The Pillar Function of the Speeches of Wisdom: Proverbs 1:20-33, 8:1-36 and 9:1-6 in the Structural Framework of Proverbs 1-9, BZAW 429 (Berlin and Boston: De Gruyer, 2012). P. W. Skehan (Studies in Israelite Poetry and Wisdom, CBQMS 1 (Washington, DC: Catholic Biblical Association of America, 1971)) argued that this is metaphorical for Wisdom's 'house' being Proverbs 1-9 itself. Others have seen the house with its seven pillars as representative of the universe with seven planets, possibly even an allusion to Ishtar of the Stars or to the Queen of heaven. Christine Yoder suggests that the seven pillars symbolise completeness and perfection, wealth and status, and that affluent and moderately wealthy members of an urban, commercial class are her audience. See Christine R. Yoder, Wisdom as a Woman of Substance, BZAW 304 (Berlin and New York: Walter de Gruyter, 2001), p. 103.

30 Whybray, 'City Life in Proverbs 1-9', p. 247. 
hardly surprising since ‘by me kings reign’ (8:15a) - one would expect her to be from an affluent context.

The figure of Woman Folly also contains much imagery of the house and its lush interior, largely because rather than being outside in the streets, this woman is portrayed as based at home, entertaining in a covert manner in secret, behind closed doors. In 9:14, she sits 'at the door of her house, on a seat at the high places of the town'. She is still depicted as in a 'high place', hence in a prominent position, as Wisdom was, too. ${ }^{31}$ She, too, invites the unsuspecting to dinner, again possibly reflecting the social customs of life in the city. The comment is made, however, that her bread and water are deceptive and that the guests at the dinner party are the dead. In 7:6-23 a young man making his way to the strange/adulterous woman's house is described in a first person account by an onlooker: it is evening when the protagonists might hope to be unnoticed, but this observant onlooker sees all. The woman then comes out of her house 'decked out like a prostitute', her feet not 'staying at home': now she, like Woman Wisdom, is 'in the street ... in the squares ... a every corner', lying in wait for her victim. Her husband is described as being away from home, on a journey, so the coast is clear for a night of love. The city context is clearly the same as that of Woman Wisdom, although the emphasis falls more on the private home than on the gates, streets and squares of the city. The unnamed husband may well be a businessman - he took a bag of money away with him and he is away for a few days. This same woman is implicitly described in 2:16-19 in the reference to the adulteress. Whybray makes the comment that the warnings against sex with a married woman 'were clearly common features of life in Israelite cities, where anonymity would make discovery and identification of the culprits less likely than in smaller communities where the inhabitants would be more aware of the behaviour of their neighbours' children'. 32 I am not sure that one can make a definite distinction between this kind of behaviour in urban and rural contexts, although clearly the dark street corners of the city are a helpful cover for illicit activity. ${ }^{33}$

These two figures are clearly figurative types representative of two moral choices on offer for the as yet uneducated youngster. Yet even if we are not to take them literally, it is interesting that an integral part of their description

31 This 'high place' could be some kind of acropolis. Perhaps there is even an overtone of a worship context in the reference to high places in relation to both these figures.

32 Whybray, 'City Life in Proverbs 1-9', p. 250.

33 See Nancy Tan, The 'Foreignness' of the Foreign Woman in Proverbs 1-9: A Study of the Origin and Development of a Biblical Motif, BZAW 381 (Berlin: Walter de Gruyter, 2008), for a thorough study of the different female characters in this section. 
is against the background of the city. Indeed all of the concrete description of a city background for Proverbs 1-9 comes through these figures. And yet little is really learnt about the city - there is nothing about its social life and interrelationships. ${ }^{34}$ The description tells us more about the use of these idealised women as they are given a city context than about the city per se. ${ }^{35}$ The question is raised, therefore, of why these two figures are presented in this elevated way in such city-orientated terms. Yoder makes the insightful comment (in a footnote) that 'It is no surprise that Wisdom (the epitome of all that is virtuous and valuable) is found in a city (the alleged epitome of culture). There is a congruent interplay between the woman and her physical setting. Where else would one expect to find her? ${ }^{36}$ One might wonder, however, if this comment also applies to Woman Folly who is found in the same context.

As I mentioned at the start, the city has more overtones than just the place: it is the hub of human activity in an area; it is associated with culture, education and wealth; and it does tend to be the base of the powerful, whether kings or other rulers. Thus the city does conjure up the image of being at the heart of the community. It is interesting that Woman Wisdom, who, after all, has a direct connection with the Godhead, is positioned in this context. This fact may suggest a divine dimension: God is active in the city in his choice of its rulers and kings and in his interaction with his people. This is not to the exclusion of the countryside, but the city is a natural focus,

34 Whybray points out that there is very little in the Old Testament generally about the social and domestic life of the city in ancient Israel: the prophetic books contain much about the shortcomings of its citizens but little of their possible virtues or daily lives. He writes, 'The literature of the Old Testament rarely shows an interest in individuals except for those who were politically prominent, desperately wicked or outstanding in some other way' ('City Life in Proverbs 1-9', p. 243). He sees the wisdom literature as a partial exception; e.g. Job 29 describes the way Job helped the poor when he himself was a leader of his community, and in Ecclesiastes there are 'glimpses' of the activities and concerns of the citizens of Jerusalem (especially with money and work) in his day.

${ }^{35}$ For more factual information about the Israelite city, see F. S. Frick, The City in Ancient Israel, SBLDS 36 (Missoula, MT: Scholars Press, 1977), pp. 25-61.

36 Yoder, Proverbs, p. 93. Yoder suggests a Persian dating for Proverbs 1-9, arguing that this setting fits well with the evidence of urbanisation and urban planning in the Persian period, particularly in cities located along the coast. I wonder, however, if there is enough evidence to establish such a conclusion. She points to Neh. 2:17-18 and 3:1$4: 6$, in which Nehemiah initiated the restoration of city walls and gates in Jerusalem. In this context, street corners and squares are mentioned using the same vocabulary as Proverbs. C. H. Toy, Proverbs, ICC (Edinburgh: T\&T Clark, 1899), who compared urban references in Ben Sira, suggested the Hellenistic period as the possible date of Proverbs 1-9 and argued for a Hellenistic city model reflected here. 
given its larger population and centrality in human life. Woman Wisdom forms a bridge between the divine and the human, and it is in the city that she makes her call. Her counterpart, Woman Folly, has to exist in the same milieu, and in many ways the city is the natural home of the prostitute (if that is indeed what she is) who is seeking out many victims and making money from the activity. With her portrayal, however, as I have noted, it is the interior of the house and its luxury furnishings that form the heart of the description.

There are some interesting links between this imagery and that employed in another book with a Solomonic connection (if not itself a wisdom book), the Song of Songs. Here too there is a city background for much of the book. There is a chase through the city streets when the woman is desperately seeking her lover, and there is a meeting at the woman's mother's house $(3: 1-15)$. The encounter with the watchmen is clearly set at the city gate (5:7), and there is an early morning excursion into the countryside in $7: 11-$ 13. I have argued elsewhere that there are extensive hints of the figures of both Wisdom and Folly in the descriptions found in the Song, ${ }^{37}$ and this would add further evidence to their contextual home in the city, both outside in the streets and squares and at home amongst luxurious furnishings.

\section{Conclusion}

In conclusion, the evidence of a city background for Proverbs 1-9 is based almost exclusively on the figures of Woman Wisdom and Woman Folly whose city location indicates a divine/human centrality that may mirror the divine realm. ${ }^{38}$ The evidence for city life elsewhere in Proverbs is sparse, but there are some significant references in the main maxims section which suggest that to draw a strong line between the contexts of Proverbs 1-9 and the rest of the book is misleading. Rather, the knowledge of the city and what

37 K. J. Dell, 'Does the Song of Songs have Any Connections to Wisdom?', in Anselm C. Hagedorn (ed.), Perspectives on the Song of Songs, BZAW 346 (Berlin: Walter de Gruyter, 2005), pp. 8-26; cf. Claudia V. Camp, Wisdom and the Feminine in the Book of Proverbs (Sheffield: Sheffield Academic Press, 1987), for the comparison with Woman Wisdom; and David Grossberg 'Two Kinds of Sexual Relationships in the Hebrew Bible', Hebrew Studies 35 (1994), pp. 7-25, for the links with Woman Folly.

${ }^{38}$ For a fascinating study of how the divine realm is largely painted in urban terms and the splendour of the city seen as a reflection both of royal power and divine glory, see Philip Davies, 'Urban Religion and Rural Religion', in Francesca Stavrakopoulou and John Barton (eds), Religious Diversity in Ancient Israel and Judah (London: T\&T Clark International, 2010), pp. 104-17. Davies discusses the problem of the marginalisation of the rural context, given that biblical texts tend to have been written in urban settings. Whether one can assume such a setting for the maxims sections of Proverbs is a question for another day. 
it stands for is widespread across the book. The difference in genre across the different sections does not make any difference to this assessment. Nor is a city context for the composition of either section implied in the material there is simply not enough evidence. Finally, the dichotomy between the two 'worlds' of Proverbs is in many ways implicit in the way the material itself tends to play up the contrasts between types. The Wisdom/Folly archetypes epitomise this contrasting typology. However, I would argue that it has been too sharply taken up in the scholarship, and that the nuance of more widespread references to city life tends to have been lost. 